\section{Coal-fired power plants face delay in United States}

In a case that could have wide-ranging implications for future US power plants, a federal appeals board has ordered the Environmental Protection Agency (EPA) to reconsider a decision not to regulate carbon dioxide emissions from a coal-fired plant in Utah.

On 13 November, the EPA's Environmental Appeals Board rejected environmentalists' claims that the agency must regulate $\mathrm{CO}_{2}$ emissions from a 110-megawatt power plant planned by the Deseret Power Electric Cooperative. But the board also rejected the EPA's argument that it cannot do so because of historical precedent.

The case hinges on a 2007 Supreme Court ruling that the EPA has the authority to regulate greenhouse-gas emissions from automobiles. Environmental groups contend that the authority should extend to the power sector, too.

Recognizing the precedent, the appeals board recommended that the EPA address the question at the national level. Presidentelect Barack Obama's campaign has said it would pursue such authority if Congress does not act on global warming.

\section{US court allows sonar exercises to continue}

The US Supreme Court has ruled that national security trumps environmental law, at least in the case of whales and sonar. Following the decision, the Navy no longer has to stop sonar training exercises off the southern California coast if whales, dolphins and other marine mammals are spotted nearby.

In a 5-4 ruling released on 12 November, the court rejected arguments that the restrictions were necessary to protect the animals from becoming harmed or disoriented by the sonar. The concerns are "plainly outweighed by the Navy's need to conduct realistic training exercises to ensure that it is able to neutralize the threat posed

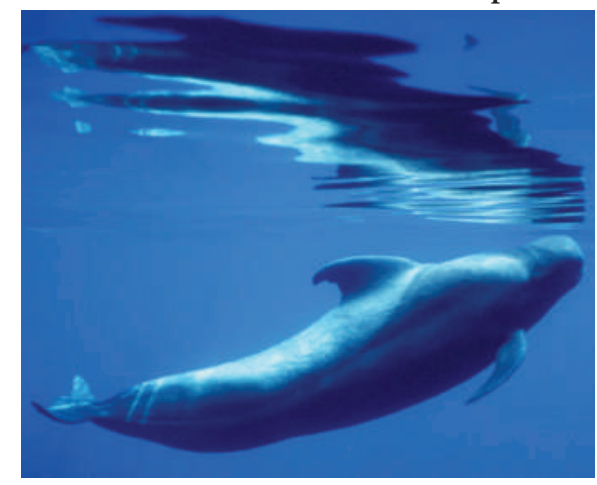

Whales will have to put up with the US navy's training exercises.

\title{
Indian space mission stakes its claim on the Moon
}

A small probe launched from the Indian Space Research Organisation's (ISRO) craft Chandrayaan-1, now in orbit around the Moon, slammed into the Shackleton crater close to the Moon's south pole on 14 November. The probe, about 40 centimetres wide, sported the Indian flag painted on its sides and collected data during the descent that ISRO says will help to plan a future landing mission. Chandrayaan-1, India's first unmanned lunar mission, will circle 100 kilometres above the Moon's surface for the next two years. This image was taken by its Terrain Mapping Camera from lunar orbit the day after releasing its impactor probe, and shows the bright rim of the 117-kilometre-wide Moretus crater at the Moon's south pole.

by enemy submarines," Chief Justice John Roberts wrote for the majority opinion in Winterv. Natural Resources Defense Council. For a longer version of this story, see http://tinyurl.com/6jvxor.

\section{Drug giant shows its commitment to stem cells}

On 14 November, pharmaceutical company Pfizer announced the formation of its new stem-cell research unit, Pfizer Regenerative Medicine, which will be based in two locations on either side of the Atlantic. The site in Cambridge, UK, will focus on neural disorders, whereas the base in Cambridge, Massachusetts, will explore applications of stem-cell technology to endocrine and cardiac research.

The centres will employ about 70 scientists in total, and Pfizer plans to announce additional collaborations with academia and industry in coming weeks.

Pfizer already has a long-term interest in cell-based therapeutics, but its expanded commitment to stem-cell research is indicative of a recent investment trend by other large pharmaceutical companies eager to use stem cells for drug screening, including GlaxoSmithKline, based near London, and the Swiss companies Roche and Novartis.

\section{Ecstasy could augment the benefits of psychotherapy}

The controversial drug MDMA - also known as ecstasy - can help ease the effects of post-traumatic stress disorder, according to the first phase-II clinical trial into the potential therapeutic benefits of using the drug as an adjunct to psychotherapy.

Most patients in the trial who were given psychotherapy along with doses of MDMA (3,4-methylenedioxy-N-methyl-

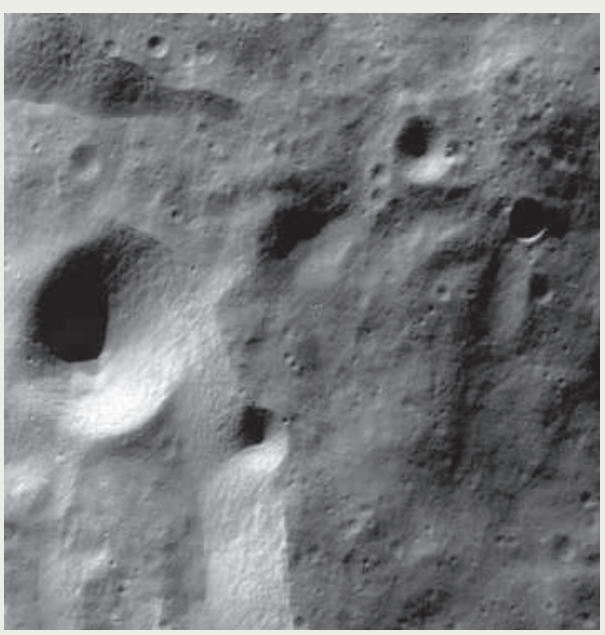

amphetamine) experienced statistically significant reductions in the severity of their condition after two months, compared with a control group who received psychotherapy and a placebo. The results, which have yet to be submitted to a peer-reviewed scientific journal, were presented on 13 November at the International Society for Traumatic Stress Studies convention in Chicago, Illinois.

"It's important to realize this is a small pilot study and it will be necessary to replicate the results elsewhere," says Michael Mithoefer, a private-practice psychiatrist based in Mount Pleasant, South Carolina, who led the study, funded by the Multidisciplinary Association for Psychedelic Studies, an advocacy group based in California. "But it is evidence that this should be studied further," he adds.

For a longer version of this story, see http://tinyurl.com/6b6zhp.

\section{US drug agency opens outposts in China}

In a bid to regulate imported food and medical products from China, the US Food and Drug Administration is opening three inspection offices in Beijing, Shanghai and Guangzhou this week - its first such offices outside the United States.

The agency will also set up inspection offices in India, Europe and Latin America by the end of the year, with another office to follow in the Middle East in 2009. The move signals the country's increasing attempts to tighten the regulation of imported products.

Several health scares over Chinese-made products have triggered mounting safety concerns in the United States. In the latest incident, melamine and related compounds - which contaminated Chinese dairy products, killing at least four children and causing tens of thousands more to fall ill were found in food imports from China. 